Jadwiga GRABDA

Parasitology

\title{
STUDIES ON THE LIFE CYCLE AND MORPHOGENESIS OF ANISAKIS SIMPLEX (RUDOLPHI, 1809) (NEMATODA: ANISAKIDAE) CULTURED IN VITRO
}

\author{
BADANIA NAD CYKLEM ROZWOJOWYM I MORFOGENEZĄ ANISAKIS SIMPLEX \\ (RUDOLPHI, 1809) (NEMATODA: ANISAKIDAE) W HODOWLI IN VITRO \\ Institute of Ichthyology, \\ Department of Fish Diseases and Parasitology
}

In the present paper the results obtained during in vitro rearing the 3rd stage larvae of Anisakis simplex (Rud.) from Baltic herring and eggs produced by the reared females are summarized. The morphology of developmental stages obtained, i.e., the 3rd and 4th larval, adult males and females, eggs and first larval stages, is described. Different organs being formed during metamorphosis of the nematodes reared are followed.

\section{INTRODUCTION}

Specific identification of larval nematodes is an extremely difficult, often impossible, task. The key taxonomic features are usually those revealed by adults, like mouth apparatus, spicules, number and position of male postanal papillae and others entirely absent from larvae. These, on the other hand, possess some larval structures (a boring tooth atop the head, a mucron terminating the tail and other) that disappear on metamorphosis.

Furthermore, considerable are the differences between each larval stage of the same species. Alimentary and excretory systems develop almost completely as late as in the 3rd stage, whereas the reproductive one is not yet developed then. 
The knowledge of the nematodes' life cycle as well as a possibility to identify the species accurately is particularly important as far' as the anisakid nematode larvae occurring in fish are concerned. The scientific literature refers only to their generic names (Anisakis sp., Terranova sp., Contracaecum sp.). However, these genera include some species that can accidentally invade man, their identification being, in view of the human health, very important.

Only the experimental studies through an artificial infestation of arimals by suitable developmental stages of larvae or through in vitro rearing of larvae and eggs can properly elucidate the life cycle.

A number of workers using variety of methods reared the 3rd stage Anisakis obtained from different fish. Grainger (1959) reared in vitro the larvae in a buffer $\left(\mathrm{Na}_{2} \mathrm{PO}_{4}\right)$, pepsine added. To stimulate moulting he supplied the medium with fresh fish flesh. Khalil (1969) used a commercially available „Medium 199" with a liver extract and horse serum. Gibson (1970) studied the development of the Anisakis larvae in rats experimentally infested through surgically grafting the larvae on the stomach wall. The rats were then killed at intervals and the larvae examined. In order to promote the infestation of rats, Gibson - basing on Granger's results - fed them with frozen fish. The medium used by Schulz (1974) consisted of nestling embryo extract, liver, porcine serum and hydrolyzed protein. Sommerville (1974) also reared the larvae on „Medium 199" adding various concentrations of gaseous carbon dioxide.

All the authors referred to above failed to obtain sexual maturity in the larvae; they could only go as far as to the 4 th larval stage preceding the adult.

Banning (1971) is the author of the only so far effective culture method. He extracted the 3rd stage Anisakis larvae out of the fish viscera using pepsine + citric acid (the mixture prepared after Roskam (1966). The larvae thus obtained were immediately placed in a medium prepared from a pH 2 - fresh bovine liver extract enriched by the cattle blood + sodium citrate; Mycostatin, a fungicide, was also added to prevent moulding. At $34-37^{\circ} \mathrm{C}$, Banning succeeded to obtain mature males and females of Anisakis identified as Anisakis marina L. according to Van Thiel (1966). In a later joint work based on the materials previously collected, Pippy and Banning (1974) changed the name to Anisakis simplex (Rud.).

Banning conducted his observations on larvae derived from freshly caught North Sea herring, mackerel and redfish.

To check the nematode species occurring in the Southern Baltic herring, an attempt was made to rear the 3rd stage larvae found in Baltic herring; a modified Banning method was used.

Adult males and females obtained were identified as Anisakis simplex (Rudolphi, 1809), the determination being based mainly on Davey (1971).

\section{MATERIAL AND METHODS}

The Anisakis larvae were obtained from herring (Clupea harengus L.) caught at the Pomeranian Bay. No artificial digestion was used, the larvae being instead mechanically 
released from the surrounding membrane. The larvae were placed, one or two each, in medium - filled vials, assuming $2-3 \mathrm{ml}$ of the medium for one larva. The vials were stopped with cotton wool and placed in a thermostat adjusted to $36-37^{\circ} \mathrm{C}$.

\section{Preparation of the culture medium}

$500 \mathrm{ml} 0.9 \% \mathrm{NaCl}$ solution, $1.25 \mathrm{~g}$ pepsine (to obtain $0.20 \%$ pepsine solution), and $5 \mathrm{ml}$ hydrochloride acid (to adjust $\mathrm{pH}$ to $1-1.5$ ) were added to $100 \mathrm{~g}$ grated bovine liver.

The resulting mixture was placed in a thermostat pre-set at $36-37^{\circ} \mathrm{C}$ for $14-16$ hours, after which time $\mathrm{pH}$ is adjusted to 2 with $\mathrm{NaOH}$ and the mixture centrifuged at $3500 \mathrm{rev}$.

The light - yellow liquid centrifuged was decanted to flasks and autoclaved for $1 / 2$ hour at $120^{\circ} \mathrm{C}$. No fungicides or antibiotics were added. The liver extract obtained can be stored as long as desired in a refrigerator at $0^{\circ} \mathrm{C}$. To avoid any contamination of the medium through frequent opening of flasks, the extract was decanted to small $200 \mathrm{ml}$ Erlenmayer flasks.

The cattle liver extract is the main ingredient of a medium for the Anisakis larvae, 1-2 drops of fresh cattle blood per larva being added.

The blood was collected axenically in sterilized flasks containing glass beads, the formation of clots being prevented by shaking the flask. No conservants like heparin or sodium citrate were used. A flask with blood could be kept in a refrigerator for 10 days before hemolysis would occur. As a rule fresh blood was collected once a week.

The culture of larvae was tested daily, each time transferring them to other sterile vials following a rinse of the larvae with sterile physiologic solution.

The blood admixture in the medium was increased by 1-2 drops at a few days intervals concordant with growth of the larvae. After the first moult they were transferred to larger vials grouping 2-3 larvae in each and supplying them with a suitable amount of the medium. Similarly, the second moult being over, 4-5 nematodes were grouped together to enable mating.

Basically, the medium and vials were changed daily except for Sunday. In a few instances, however, the larvae were maintained in unchanged medium for 2-3 days dispensing only $1-2$ drops of blood per larva each day. These breaks bore no visible effect on viability and further development of the larvae.

Sterile conditions seem to be very significant for a successful culture. The process was triplicated and each time the adults were obtained, no bacterial or fungal contamination occurring.

However, not all the larvae were able to reach the last stage. Some of them died out during the culture period, most often on moulting, so that about $50 \%$ of the original number reached maturity. As a result 6 males and 8 females were obtained.

During the culture period some nematodes were fixed and preserved for further studies on morphology of each stage.

Alcohol with glycerine or $75 \%$ pure alcohol, at room temperature or heated, was used for fixation. When examining the adult forms, various organs like lips, intestine, spicules were dissected. Additionally, for each Anisakis stage microtome cross-sections of 
different parts of the body were made. The sections allow the larvae found in tissues of man and animals to be identified to the specific level, which makes a diagnosis easier. The works by Chitwood and Chitwood (1950) as well as Chitwood and Lichtenfels (1972) were referred to when studying the larval anatomy.

Eggs for a further culture were collected from the reared ovulating females. With this aim in mind, the females were washed clear of the remains of the medium with the physiologic solution, following which they were placed in sea water - filled crystallizers, the latter being then put in a thermostat. After 2 hours the females were re-transferred to the normal medium. Meanwhile a large number of eggs concentrated on the bottom of the crystallizer. These were incubated at room temperature $\left(22-24^{\circ} \mathrm{C}\right)$.

\section{THE COURSE OF THE IN VITRO CULTURE OF THE 3rd LARVAL STAGE}

The culture proceeded from March till May 1973 in three series of experiments, 43 larvae being reared altogether.

In the first two series the larvae collected directly from fresh herring next day after capture were used, while for the third one the larvae were at first kept for 5 days in the physiologic solution at $2^{\circ} \mathrm{C}$.

Adult, sexually mature nematodes resulted from each series.

Immediately after taking them out of fishes the larvae were very active and swimmed, performing wriggling movements. Having placed them in the medium in a thermostat they usually lied still on the vial's bottom for a few days, their weak movements becoming more vigorous only on transfer to a fresh medium.

After 4-7 days moulting occurred, after which the larvae clearly got bigger and their movements became more intense; their cuticle showed a discernible transverse striation while some sanguineous substance showed through intestine. That was the fourth larval stage (pre-adult).

The next moult took place after next 12-14 days, resulting in an adult, sexually mature stage. Whitish cord - like gonads showed through the cuticle.

After 4-9 days following the second moult eggs appeared in the culture vessel.

One batch of nematodes ( 3 females +2 males) was reared on until the females were finished out and the egg production ceased. This period lasted 14-19 days, after which shrunk and lessened females died.

The whole period of rearing, till new eggs appeared, took 23-29 days in the experiments described above (J. Grabda, 1975).

\section{DESCRIPTION OF DEVELOPMENTAL STAGES OF ANISAKIS SIMPLEX}

\section{3rd stage larva (Figs. 1-6)}

The larvae usually occur in the herring body cavity coiled into flat spirals and encysted in or under the peritoneal membrane. Most often they are found along the intestine between gonads and on the blind diverticulum of the stomach. They dwell also, although 
more seldom, under the perihepatis and gonad mernirane, between pyloric processes and in muscles. Sometimes they are not encysted, their anterior end in the ventral muscles and the posterior one protruding into the fish body cavity. Also they can be entirely surrounded by the muscle tissue.

About $2 \mathrm{~mm}$ behind the larval head a white spot of ventriculus is clearly seen.

Length of the larvae varies. Those used in the culture measured $19-28 \mathrm{~mm}$, the central part of the body being $0.3-0.5 \mathrm{~mm}$ wide.

The cuticle shows a delicate transverse striation of a rather plicate nature. The boring tooth is placed slightly dorsally atop the head together with 3 poorly developed lips, one dorsal and two ventro - lateral (Fig. 1). Between the ventro - lateral ones, slightly below the tooth an excretory pore can be seen, an excretory canal leading from a single excretory gland cell terminating there. The gland lies ventrally, somewhat to the left and is extended beyond the ventriculus along the intestine anterior part. The gland is fairly well visible in live larvae as a dark strip.

A muscular esophagus measures, dependig on size of a larva, from 1.8 to $2.8 \mathrm{~mm}$. Its glandular part, the so-called ,,ventriculus" $0.6-0.8 \mathrm{~mm}$ long is obliquely joined with the intestine (Fig. 3).

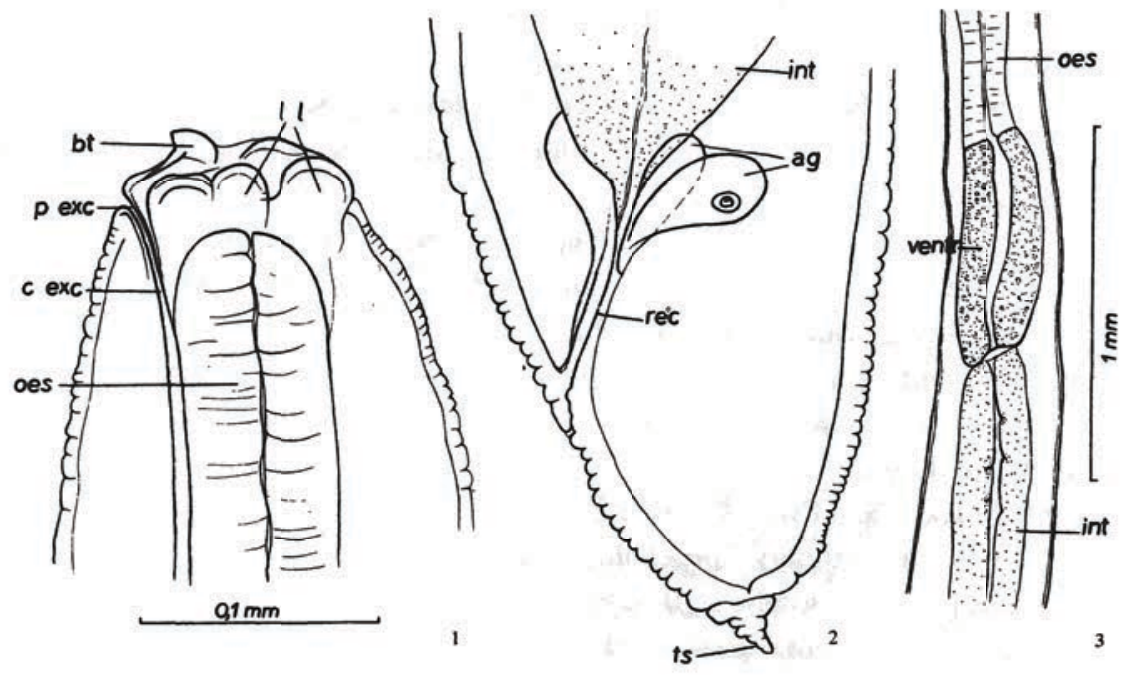

Figs. 1-3. Anisakis simplex, 3rd stage larva

Fig. 1. Cephalic part of larva, Fig. 2. Tail part of larva, Fig. 3. Region of ventriculus ag - anal glands, bt - boring tooth, c exc - excretory canal, int - intestine, 1 - labia, oes - esophagus, $\mathrm{p}$ exc - excretory pore, rec - rectum ts - tail spine, ventr - ventriculus

The rectum forms a short canal oblique to the anus, with a thick cuticular layer. 3 large pear-shaped cells are grouped around the rectum; these are the anal glands.

The tail is short, conical with a rounded tip provided with a shrinkable process (mucron) (Fig. 2). 
At a distance of $0.25-0.27 \mathrm{~mm}$ from the head top, the esophagus is surrounded by a nerve ring.

Two large lateral hypodermal chords of a compressed base and a bilobate part protruding into the larval body cavity are visible on crosssections. Numerous large nuclei are observable in the chords. The dorsal and ventral chords are much more weakly developed and do not protrude above the muscular layer of the body wall. The muscular layer is of a polymyaria type.

The esophagus is a thick - walled canal built of radially arranged muscles, glandular cells with large nuclei being placed between them. The esophagus lumen is three-radial with a thick cuticular layer (Fig. 4).

The next, glandular part of the esophagus, so-called ,ventriculus" has also a threeradial lumen. Its wall is built of large glandular cells filled with a granulated substance. These cells are brightly red-stained with eosine. The ventriculus has an oblique junction with the intestine (Fig. 5).

The epithelium lining the intestine consists of a single layer of columnar cells, their paracentral surfaces being covered by short, thin processes forming a thin microvillus layer (Fig. 22). The intestine cells' nuclei are placed centrifugally, near the intestine basal membrane (Fig.6). This type of epithelial cells of the intestine does not change throughout the entire life span. The intestinal lumen is also three-radial in its crosssection, so that the intestinal cells are of unequal length. The whole digestive tract has in this stage a fissured tightened lumen, no food particles being observed. This is an evidence of a lack of feeding in this larval stage; this state of affairs changes only after moult when the fourth stage has begun.

Along the anterior part of the intestine, „ventriculus” and esophagus, ventrally and shifted to the left runs the excretory gland. It shows a connection with the left lateral chord of hypodermis, which is clearly visible on the cross-sections at the intestinal part of the body. This contact with the lateral chord disappears anteriorly. Inside the gland there is an excretory canal, opening ventrally on the top of the head between the ventro lateral lips (Figs. 4-6).

The 3rd Anisakis larval stages show a considerable viability. The larvae taken out from a fish and kept in an ordinary household fridge at ca $2^{\circ} \mathrm{C}$ survived up to 8.5 months in a pure physiological salt solution $(0.65 \% \mathrm{NaCl})$. Usually they were observed lying still, spirally coiled on the bottom of a vessel; their movements started after placing them at room temperature. Under natural conditions, inside a fish, they presumably maintain their viability still longer living in anabiosis until they can penetrate to the digestive tract of their definite host or - more correctly - until their 4th stage.

The 3rd stage just described corresponds to the description of Anisakis sp. larva (I) given by Berland (1961). The Japanese authors denote this larva as Anisakis Type I (Koyama et al., 1969; and others). Van Thiel and Van Houten (1969), Van Banning (1971) and others use the name Anisakis marina L. Recently Pippy and Banning (1974) decided on adopting the name Anisakis simplex. 

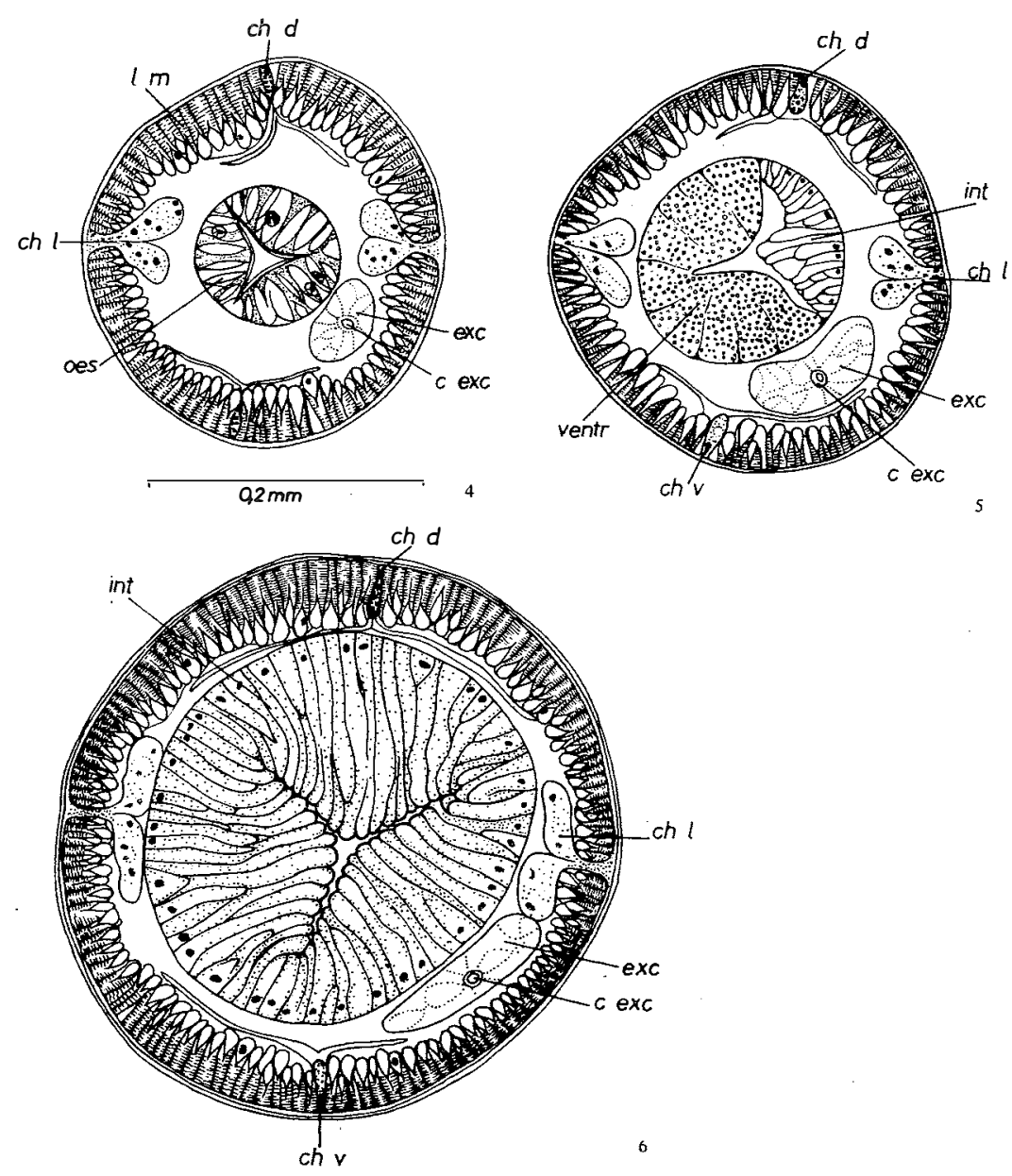

Figs. 4-6. Anisakis simplex, 3rd stage larva

Fig. 4. Cross section through esophageal region, Fig. 5. Cross section through the junction of ventriculus and intestine, Fig. 6. Cross section through intestinal region

c exc - excretory canal, ch $\mathrm{d}$ - dorsal chord, ch 1 - lateral chord, ch $\mathbf{v}$ - ventral chord, exc - excretory gland cell, int - intestine, $1 \mathrm{~m}$ - muscle cells, oes - esophagus, ventr - ventriculus

Identical larvae were found by the present author in herring and mackerel from the North Sea (Scottish fishing grounds) and from the Celtic shelf as well as in other fish species such as Baltic cod (Gadus morhua), blue whiting (Micromesistius poutassou), Australian blue whiting (Micromesistius australis), Theragra chalcogramma, Pacific herring (Clupea harengus pallasi), redfish (Sebastes marinus), hake (Merluccius productus), horse mackerel (Trachurus symmetricus), Pleurogramma monopterygius, and Anoplopoma fimbria. 
4th stage larva (Figs. 7-11;26-27)

These larvae were examined on the day following their moult. 5 specimens examined revealed slight differences in size between the 4th and preceding stage. The body length and central body part thickness ranged respectively within $25-31 \mathrm{~mm}$ and $0.45-0.7 \mathrm{~mm}$.

The cuticle became clearly striated; the striation forms a type of segments, on a side view visible as a serration.

3 well-developed lips on the head, similar to those in adults. The dorsal lip has two large papillae on either side, while the ventro - lateral lips have one papilla each. A delicate dentigerous ridge can be found on the paracentral edge of the lips. Boring tooth absent (Figs. 7 and 8).

The tail short, bluntly rounded with small papillous nod instead of a mucron (Fig. 10).

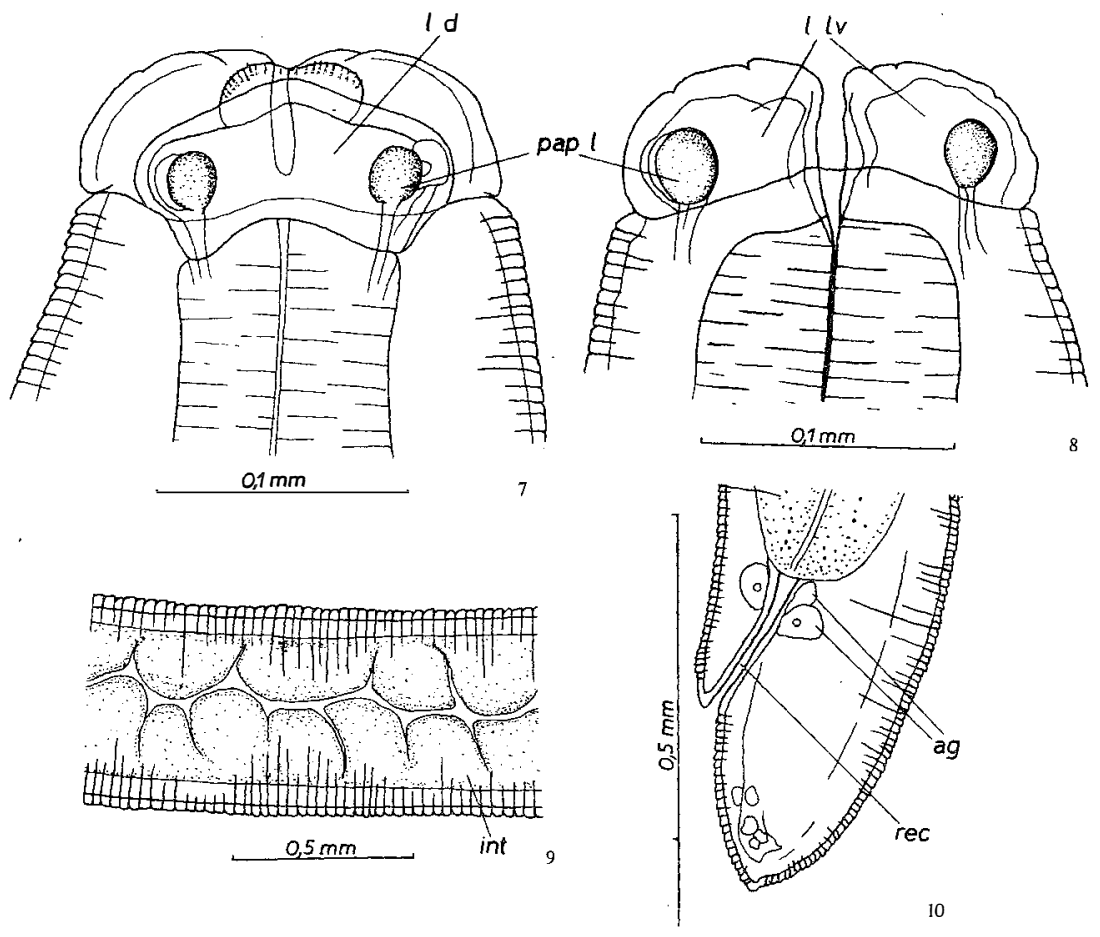

Figs. 7-10. Anisakis simplex, 4 th stage larva, pre-adult

Fig. 7. Cephalic part of larva, on the dorsal side, Fig. 8. Idem on the ventral side, Fig. 9. Central part of intestine, Fig. 10. Tail part of larva

ag - anal glands, int - intestine, $1 \mathrm{~d}$ - dorsal lip, $11 \mathrm{v}$ - ventro-lateral lips, pap 1 - labial papillae, rec - rectum

The muscular esophagus $2.2-2.4 \mathrm{~mm}$ long with the nerve ring at a distance of $0.27-0.37 \mathrm{~mm}$ from the anterior end of the body. The glandular part of the esophagus, 
the ,ventriculus", measures $0.7-0.9 \mathrm{~mm}$ in its length. The intestinal lumen clearly shows through the body wall as a zig-zagging canal filled with blood (Fig. 9).

The short rectum with a thick cuticular layer terminates in the anus. 3 large unicellular anal glands, 2 dorsal and 1 ventral, are placed next to the rectum (Fig. 10).

The intestine becomes active in this stage. The epithelial cells strongly developed, their paracentral parts broadened and rounded adopting a clavate shape on the cross-section. Growth of these cells, however, is not uniform, they are of very variable sizes thereby transforming the intestinal lumen into a star-like snape with irregular branchings. Food masses composed of blood cells and their remnants taken up from the medium are seen in the lumen.

Young and Lowe (1969) as well as Gibson (1970) also observe an activation of the intestine in the fourth larval stage.

The lateral hypodermal chords maintain their previous structure. On the ventral side below the intestine a large excretory gland can be found connected by a narrow commissure with the left lateral chord. Near the right one, also ventrally, the beginnings of gonads are discernible (Figs. 11 and 27).

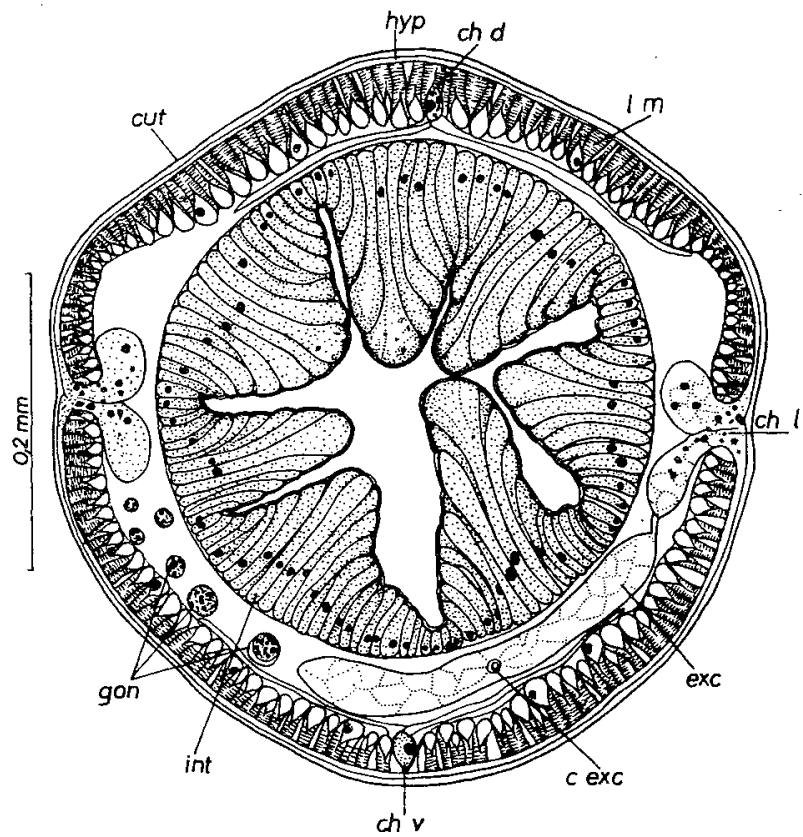

Fig. 11. Anisakis simplex, 4th stage larva. Cross section through intestinal region c exc - excretory canal, ch d - dorsal chord, ch 1 - lateral chord, ch $\mathrm{v}$ - ventral chord, cut - cuticle, exc - excretory gland cell, gon - gonads, hyp - hypodermis, int - intestine, $1 \mathrm{~m}$ - muscle cells

The larvae of this stage were very motile and grew well. The next moult took place after 12-14 days, adult nematodes resulting. 
In the same way as decribed above the 4th larval stages were obtained in vitro by Grainger (1959), Khalil (1969), Koyama et al.(1969), Gibson (1970), Banning (1971), Schulz (1974), Sommerville (1974). Of these only Banning succeeded to obtain, after 26-98 days, adult individuals. Other authors failed to terminate the development of their larvae, since the „pre-adult" forms died after some time undergoing no metamorphosis. These forms survived up to 18 and 40 days in experiments conducted by Schulz and Khalil, respectively.

The 4th larval stage was also reported to be obtained in animals experimentally infested with the 3rd stage larvae derived from fish (Gibson, 1970; Ruitenberg, 1970; and others). The stage discussed was found in a human intestine as well (Van Thiel et al., 1960). In an intestine section the latter authors found a $2.3 \mathrm{~cm}$ long larva without a mucron, with clearly striated cuticle and 3 distinct lips separated with a groove from the rest of the body. A fine dentigerous ridge was observed on one lip. These characters are typical of the 4th developmental stage, which is also indicated on the larva's cross-section by a branched intestinal lumen.

Van Thiel and Van Houten (1967) found also a larva in this stage in a human stomach and identified it as Anisakis marina ,juvenile stage". That larva had well-developed lips (like in an adult individual), no interlabia, invisible excretory pore and a distinclty striated cuticle. Both the description and photographs enclosed correspond to the 4th stage described in this paper.

Although man is not an usual host for Anisakis simplex, yet in a human digestive tract as well as in experimental animals the 3rd stage larvae are stimulated to carry on their development and metamorphosis into the 4th stage. The fact that their development can terminate in an artificial medium allows to presume that a possibility of the further development and metamorphosis of the 4th stage in a human organism cannot be rejected.

\section{ADULT FORMS}

The characterisitc features of reared adult specimens are consistent with the generic diagnosis of Anisakis Dujardin, 1845 as given by Davey (1971). Those are as follows:

The mouth surrounded by three lips: one large, dorsal and the other two smaller, ventro - lateral.

On the dorsal one near its base two labial papillae can be found, and the ventro lateral ones have 1 papilla each. Each lip has an anteriorly directed two-part lobe with rounded edges. A ridge of small denticles is placed paracentrally on the lobes (Fig. 19). No interlabia.

The long esophagus consists of an anterior, muscular part and a posterior glandular one, distinctly separated into so-called ,ventriculus". The latter is a straight cylindrical or S-shaped canal obliquely connected with the intestine (Fig. 12). Both the ventriculus and intestine without appendices. The rectum is a thin, short, oblique canal terminating in an anus. The tail short, conical. 

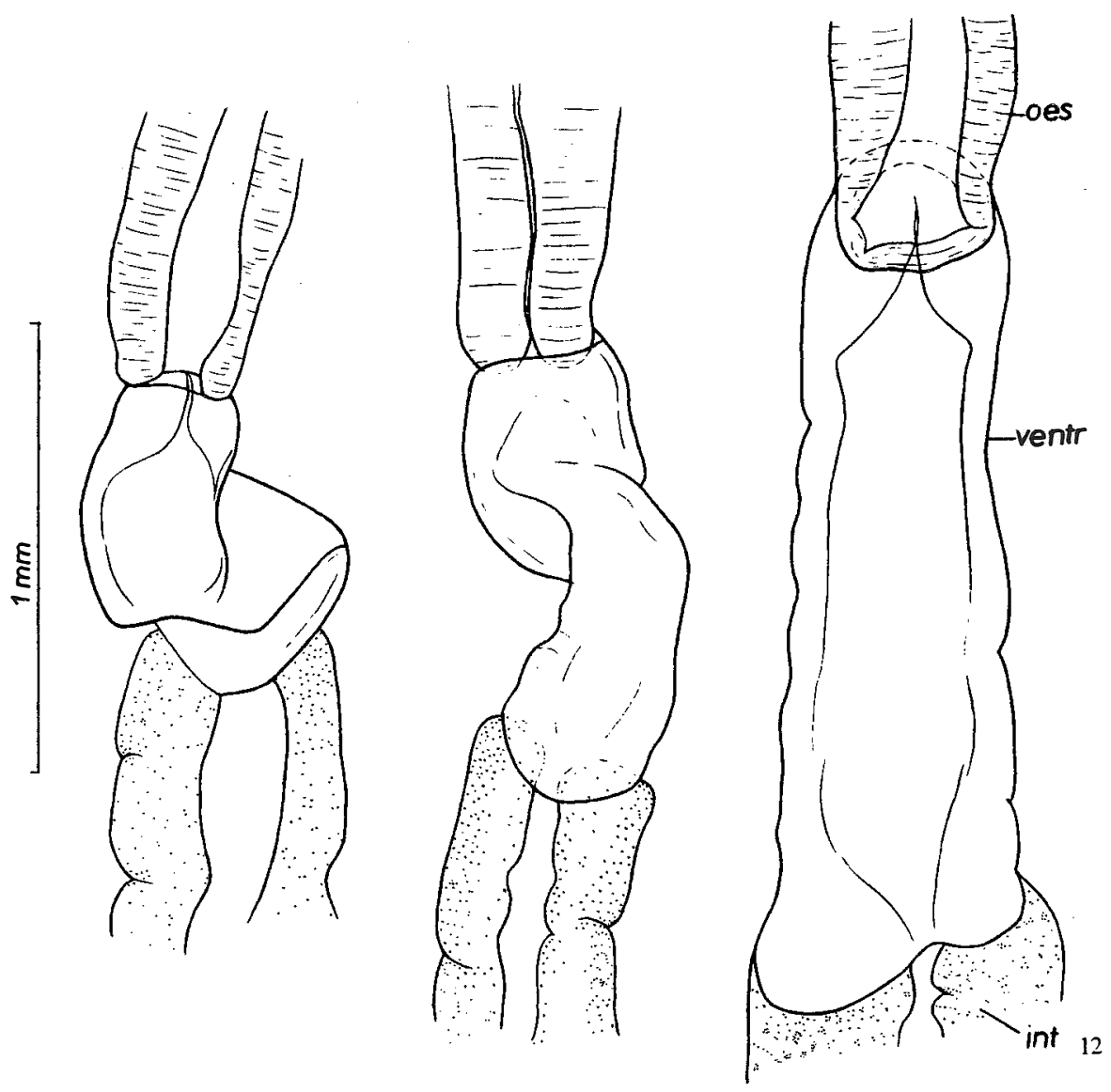

Fig. 12. Anisakis simplex, adult. Different forms of ventriculus int - intestine, oes - esophagus, ventr - ventriculus

The main specific features, adopted after Davey (1971) are: the length of ventriculus, lengths of spicules and their ratio as well as number and arrangement of male postanal papillae.

Male (Figs. 13-18; 28-30)

Our own specimens measured $5.7-7.2 \mathrm{~cm}$. Posterior ends of the body usually ventrally bent. An elongated groove with numerous preanal papillae is located ventrally in front of the cloaca. The cuticle along the groove thickened on the sides forming a kind of small alae encompassing the tail. The latter very short, conical. Its length as measured from the proximal end of the anus, is $0.3-0.4 \mathrm{~mm}$. Four pairs of papillae near the end of the tail and 2 pairs laterally to the anus. The papillae are, however, poorly discernible. 


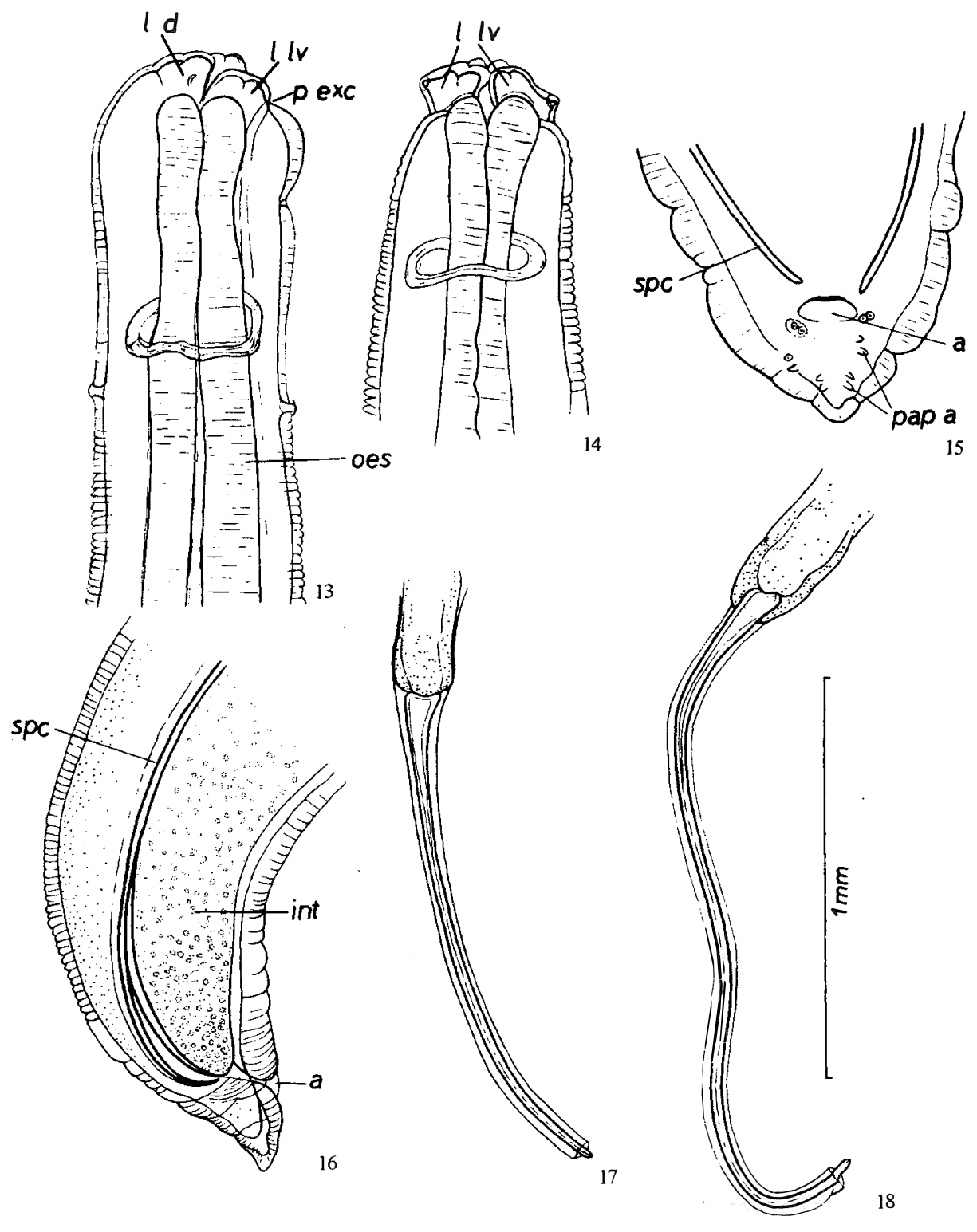

Figs. 13-18. Anisakis simplex, adult male

Fig. 13. Cephalic part of Anisakis on the right side, Fig. 14. Idem, from ventral side, Fig. 15. Tail of male on the ventral side, Fig. 16. Idem, on the right side, Fig. 17. Right spicule, Fig. 18. Left spicule of the same male. All figures made in the same scale a - anus, int - intestine, $1 \mathrm{~d}$ - dorsal lip, $1 \mathbf{v}$ - ventro-lateral lips, oes - esophagus, pap a - postanal papillae, $\mathrm{p}$ exc - excretory pore, spc - spicule 
Spicules of unequal lengths, their size depending on the size of a specimen. Right and left spicules dissected from a $5.6 \mathrm{~cm}$ long male measured respectively 1.35 and $1.97 \mathrm{~mm}$, their ratio being 1: 1.47 (Fig. 17 and 18).

At a distance of about $0.55-0.71 \mathrm{~mm}$ from the top of the head, the nerve ring surrounding the esophagus is visible, branching to the hypodermal chords. Immediately behind the ring two papillae, dorsal and ventral, can be found on the cuticle (Fig. 13).

The ventriculus straight or S-shaped, about $1.6 \mathrm{~mm}$ long.

On the microtome cross-sections the attention is drawn to lateral hypodermal chords of lobes particularly elongated and protruding to the body cavity (Fig. 30). A multi-layer thick cuticle well-visible on the same photograph.

The male intestine does not differ from that of the 4th stage larva. Its lumen is also branched star-like. An excretory gland located next to the ventriculus and the anterior part of the intestine is strongly flattened (Fig. 29).

\section{Female (Figs. 19-24; 31-36)}

Our own specimens measured $5.6-10.4 \mathrm{~cm}$ in length; their thickenss in the central part of the body reached $2 \mathrm{~mm}$.

The body is cylindrical all-over, the tail conical. Lips identical as in a male. The ventriculus can be either straight or S-shaped.

The female reproductive system typical of Ascaridida (Opisthodelphic according to Chitwood and Chitwood, 1950). The vulva is situated before the middle of the body, vagina directed posteriorly, 2 parallel uteri run towards the posterior end. Ovaries form numerous loops (Fig. 23).

The intestine of a mature female is well-developed, its lumen strongly broadened, of an irregular, oval outline, abundantly filled with food particles and epithelial cells' excretions (Fig. 23).

Lateral chords of the hypodermis in the anterior part of the body are well-developed; they do not protrude above the muscular layer along the intestine and are poorly visible in contrary to the large, well-discernible chords in males.

The excretory system of a typical structure, only an excretory gland well-developed; on the ventriculus level it loses its oval transverse outline and becomes very characteristically shaped (Fig. 35). According to Chitwood and Chitwood (1950), this type of an excretory gland is typical of senescent nematodes. However, these workers do not mention the differences between male and female excretory glands.

\section{EGG REARING}

The eggs deposited by the females reared were placed in the Baltic seawater-filled crystallizers and kept at room temperature. They lied on the bottom throughout the culture period. The eggs of size range of $39-42 \times 41-43 \mu \mathrm{m}$ had smooth, thin, translucent shells, blastomeres in various cleavage stages being visible inside (Fig. 25a). 

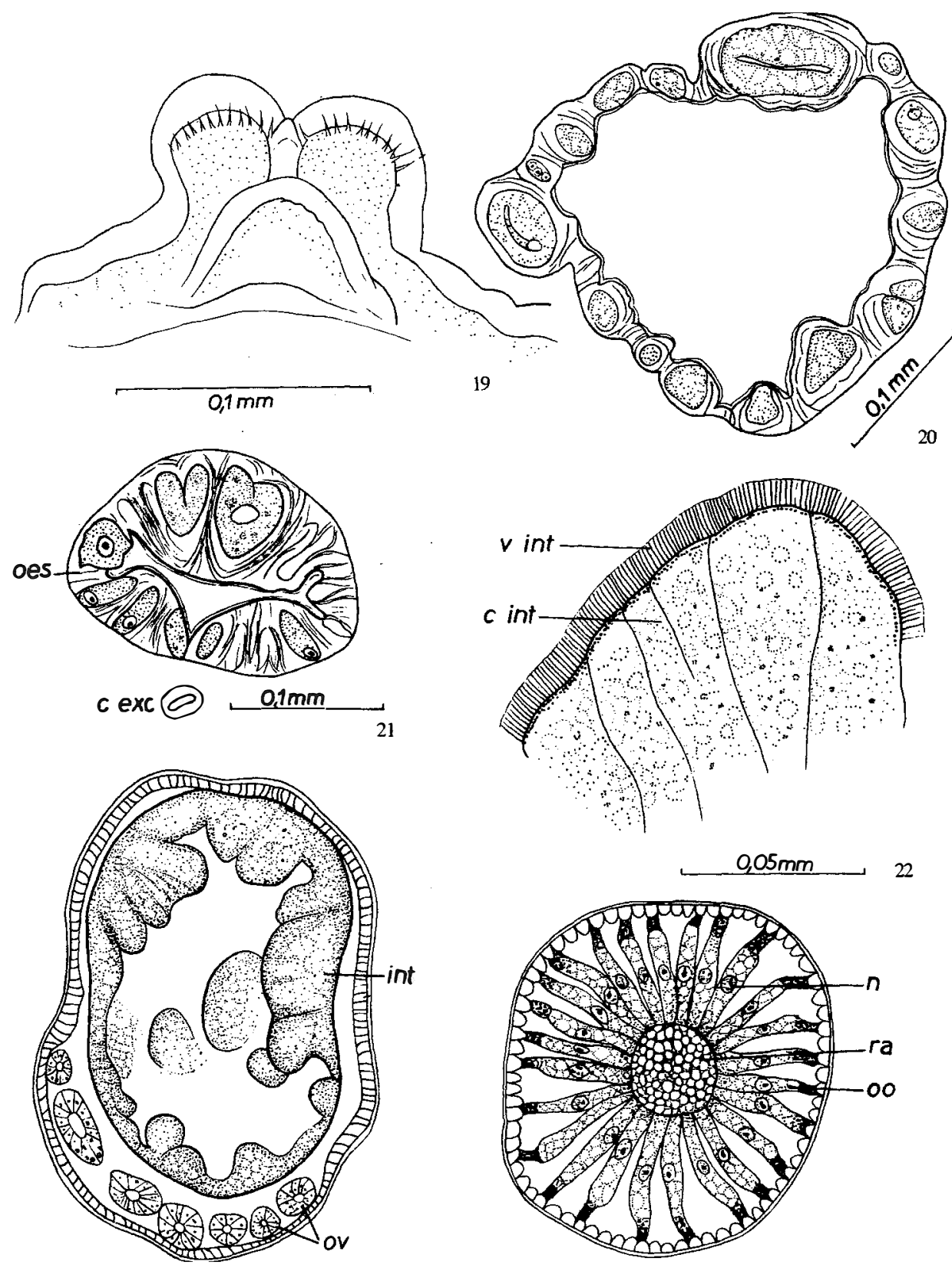

23

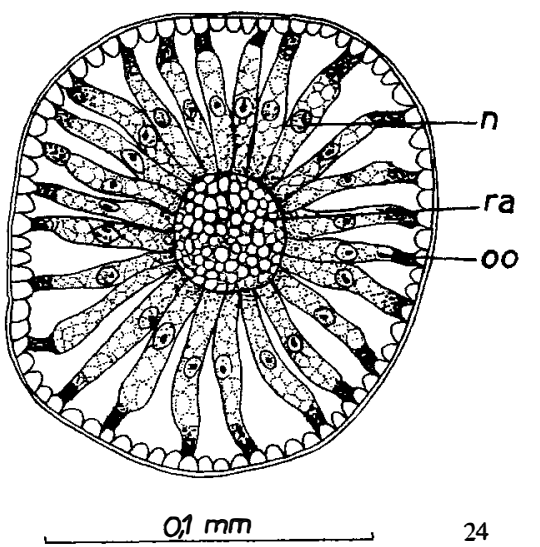

Figs. 19-24. Anisakis simplex, adult female

Fig. 19. Dorsal lip with a dentigerous ridge on the inner side, Fig. 20. Cross section of the distal part of esophagus, Fig. 21. Cross section of esophagus behind the lips showing excretory canal, Fig. 22. Cross section of the fragment of intestinal cells with microvilli, Fig. 23. Cross section through intestinal region of female, Fig. 24. Cross section through ovary

c exc - excretory canal, $c$ int - intestinal cells, int - intestine, $n$ - nucleus of oocyt, oes - esophagus, oo - oocyt, ov - ovary, ra - rachis, $v$ int - microvilli 
As early as after 2 days some eggs contained coiled, rather motile larvae (Fig. 25b). Following another 3 days most eggs contained larvae and the first larvae appeared in water. Some of them lied on the bottom, some swimmed bending their bodies in a rather sluggish manner.

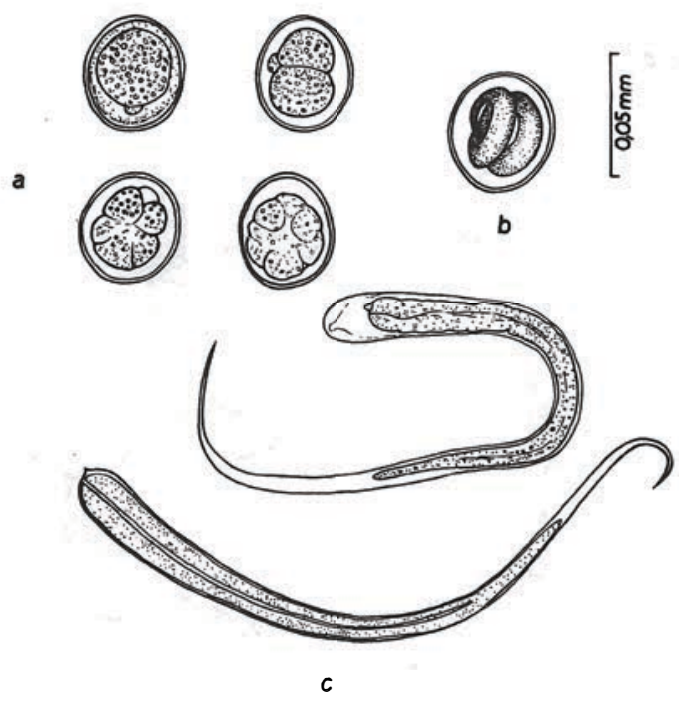

Fig. 25. Anisakis simplex, first stages of development

a. Eggs showing some stages of cleavage, b. Egg with the first stage larva, c. Free larvae of II stage withhin the sheat of I stage larvae

The larvae were covered with a cuticular sheat with a fine transverse striation. In live larvae the sheat was clearly visible in the tail part. Having fixed the larvae, their sheats got detached also in the cephalic part due to the body contraction (Fig. 25c). The sheat is a moult of the 1 st larval stage that develops inside the egg, remaining as a case for the 2 nd stage instead of being shed. Also Banning (1971), Oshima et al. (1969) and Kagei (1969) observed a similar sheat on larval Anisakis, whereas Davey (1969) and Myers (1960) found it on the same stage of Contracaecum aduncum and Phocanema decipiens, respectively.

The presence of this larval sheat in the 2nd stage larvae is a constant feature in this nematode group. It is shed when the larva has been eaten by its first intermediate host (Davey, 1969; Oshima et al., 1969).

The larval body, thickest at its anterior part, gradually tapers to the posterior, forming a long, pointed tail. A part of the tail still in the sheat is much shorter and more bluntly ended. A boring tooth, slightly asymmetrically placed, is present atop the head. Beginnings of lips completely lacking.

Internal organs poorly differentiated. The esophagus visible as a thin canal, then a poorly developed intestine. 
The larvae, as measured in their sheates, were 297-351 $\mu \mathrm{m}$ long; their maximum thickness in the anterior part ranged within 20-23 $\mu \mathrm{m}$. When measured with no sheat on, their length range was $281-293 \mu \mathrm{m}$.

The larvae lived about a fortnight in the culture, no further metamorphosis bein observed and the cuticular sheat kept on.

Neither the course of the culture nor the structure of eggs and larvae were significantly different from those observed by Banning (1971) and Japanese workers (Kagei et al., 1964); only slight differences in sizes occurred.

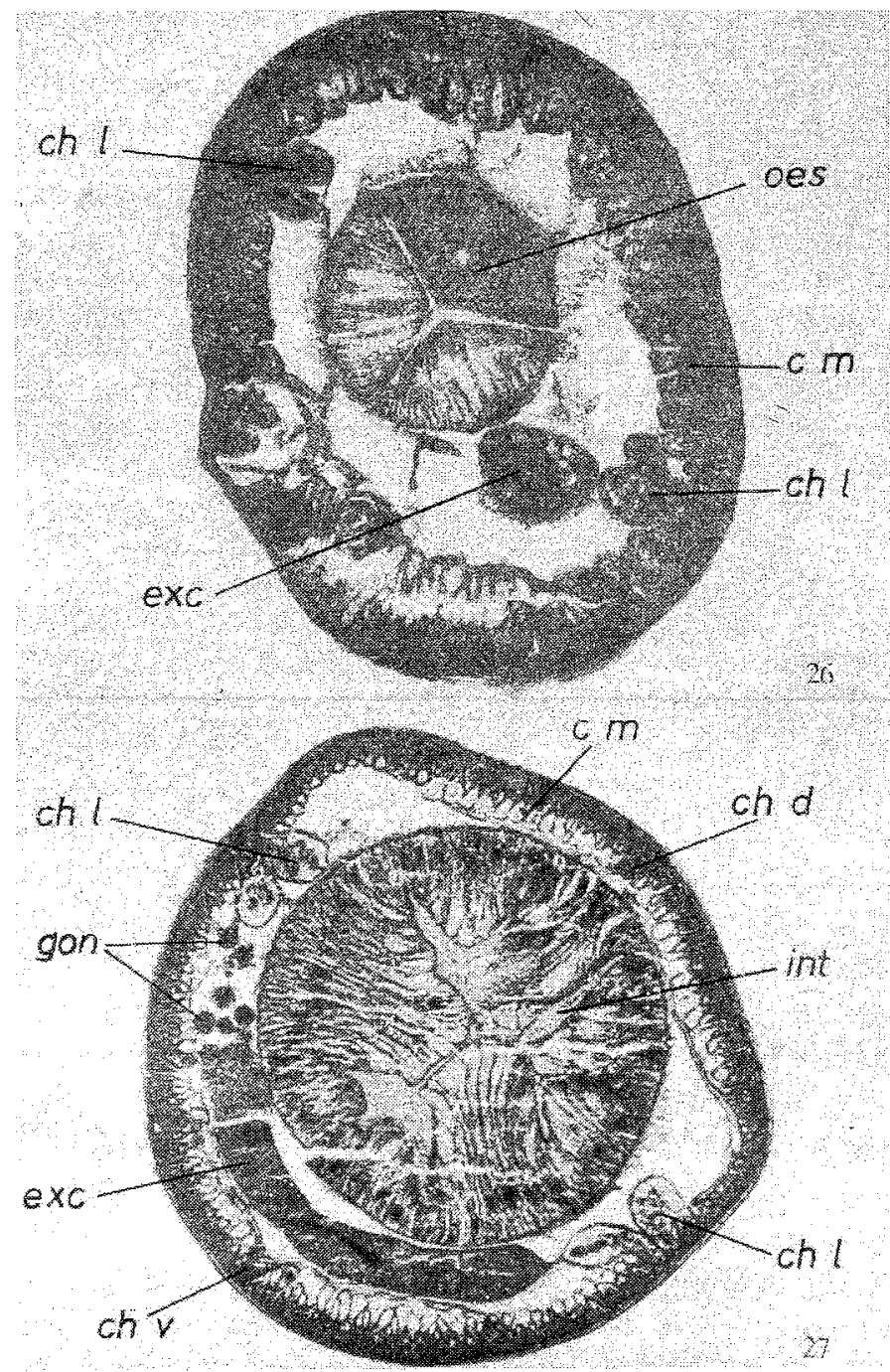

Figs. 26-27. Anisakis simplex, 4th stage larva, pre-adult. Phot. mgr Marek Strzelichowski Fig. 26. Cross section through esophageal region, $x$ 160, Fig. 27. Cross section through intestine, $x 63$ ch $\mathrm{d}$ - dorsal chord, ch 1 - lateral chord, ch v - ventral chord, c m - muscle cells, exc -excretory gland cell, gon - gonads, int - intestine, oes - esophagus 


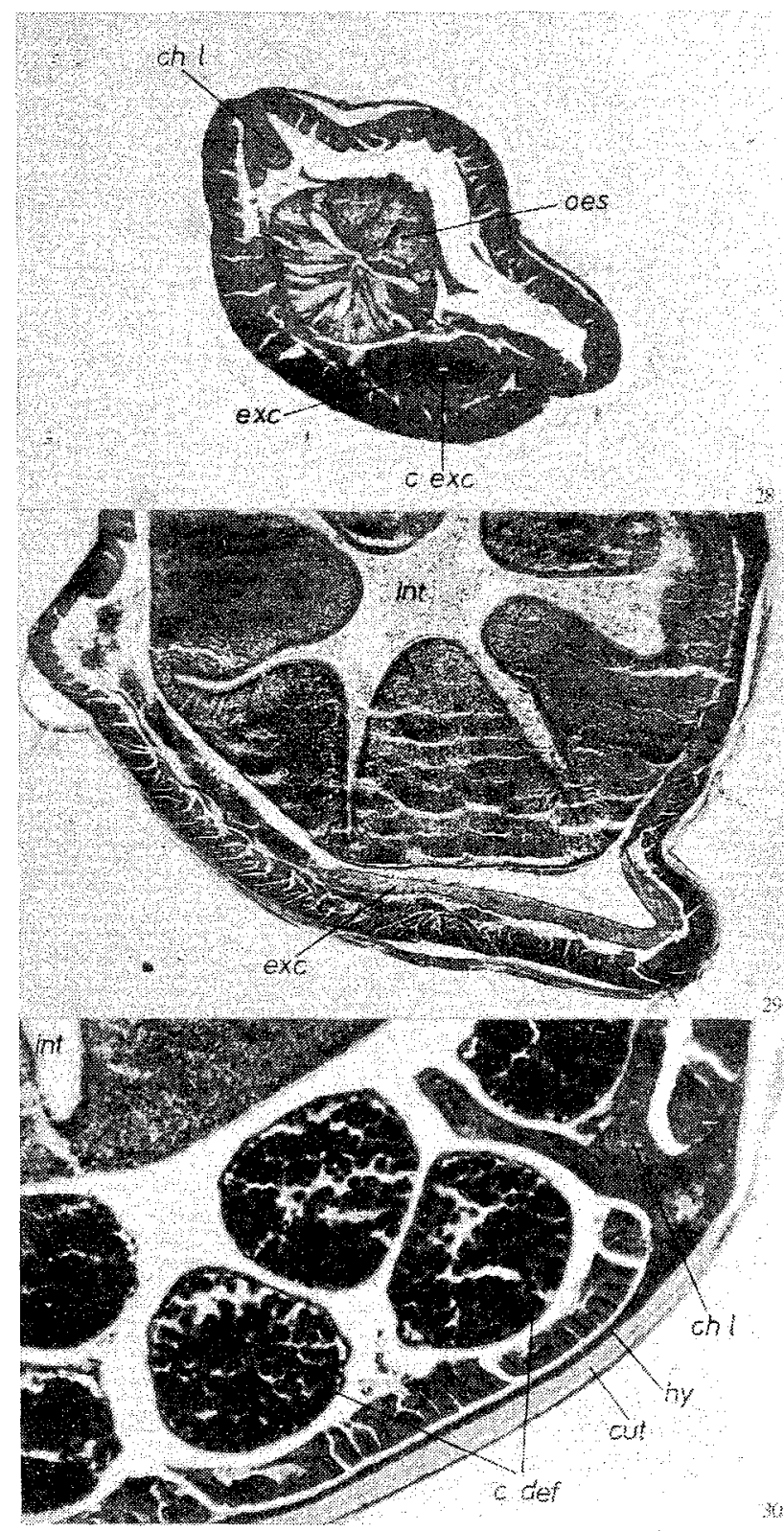

Figs. 28-30. Anisakis simplex, adult male. Phot. mgr Marek Strzelichowski

Fig. 28. Cross section through esophagus, $x$ 63, Fig. 29. Part of cross section through intestinal region, $x$ 63, Fig. 30. Part of cross section through gonads, $x 160$

c def - vas deferens, c exc - excretory canal, ch 1 - lateral chord, cut - cuticle, exc - excretory gland cell, hy - hypodermis, int - intestine, oes - esophagus 


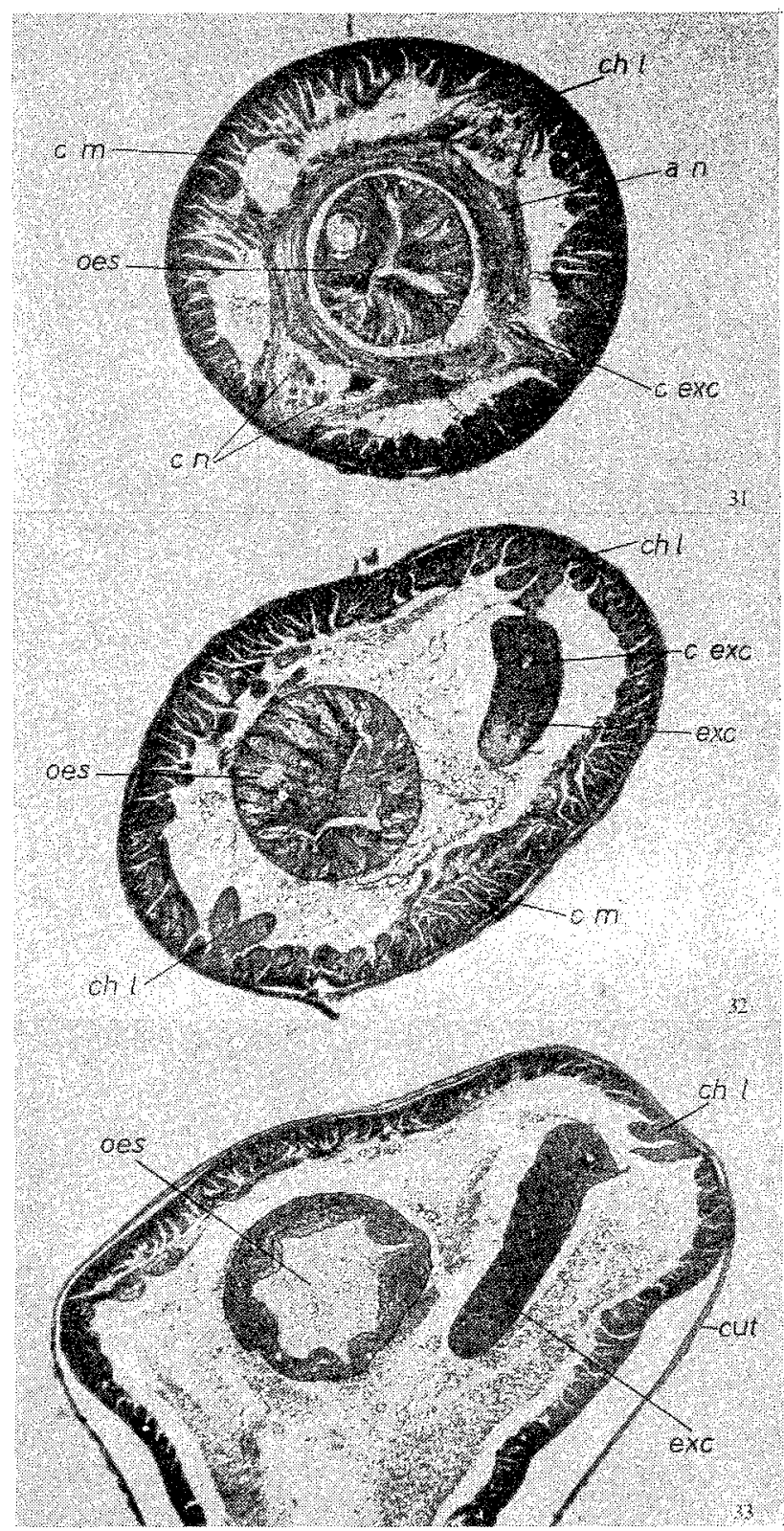

Figs. 31-33. Anisakis simplex, adult female. Phot. mgr Marek Strzelichowski Fig. 31. Cross section through nerve ring, $x$ 63, Fig. 32. Cross section through esophagus behind nerve ring, $x$ 63, Fig. 33. Cross section through distal part of esophagus, $x 63$

a $\mathrm{n}$ - nerve ring, $\mathrm{c}$ exc - excretory canal, ch 1 - lateral chord, $\mathrm{c} \mathrm{m}$ - muscle cells, $\mathrm{c} \mathrm{n}$ - nerve cells, cut - cuticle, exc - excretory gland cell, oes - esophagus 


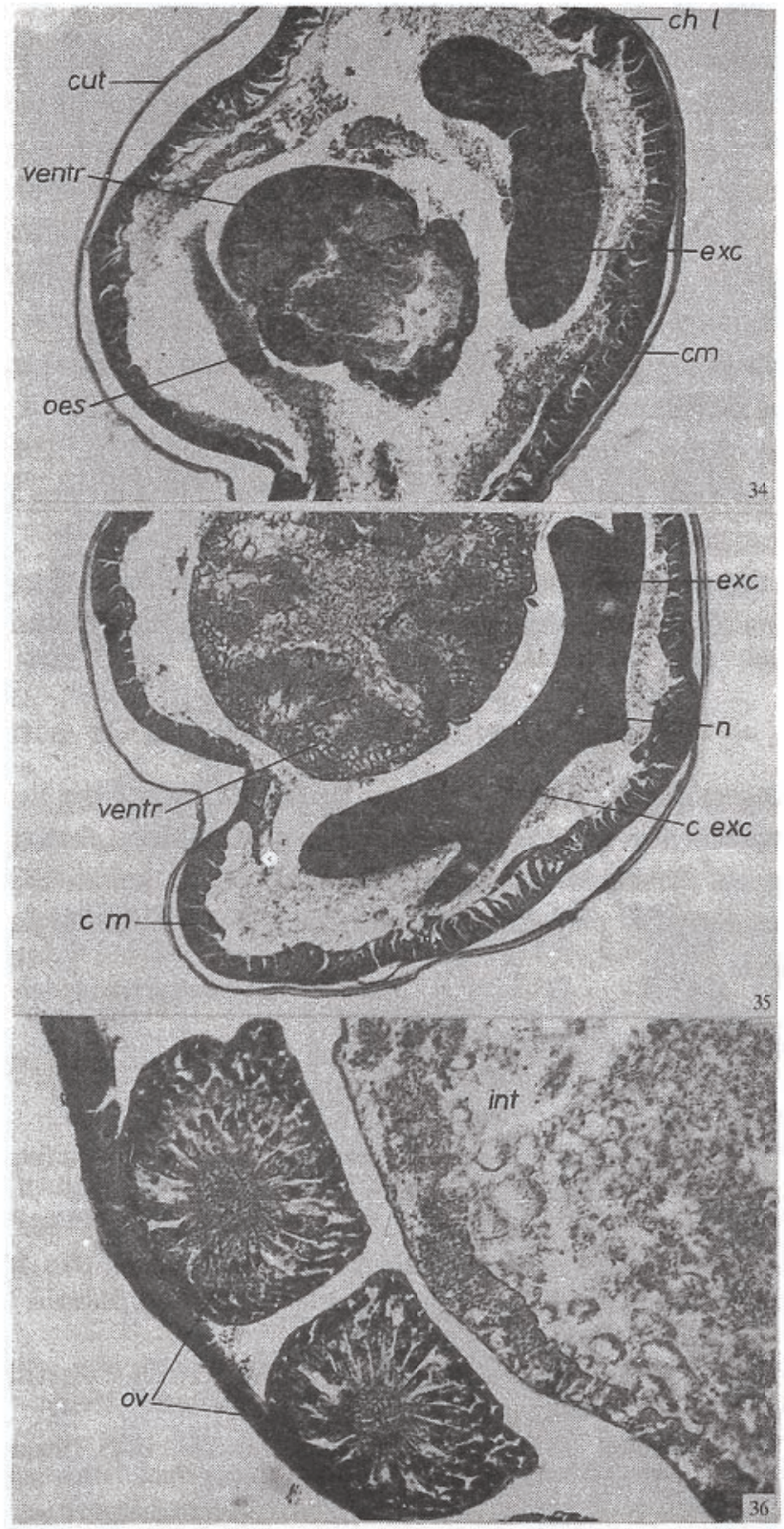

Figs. 34-36. Andsekts stmplex, aduit female. Phot. mgs Marek Strzellchowski Fig. 34. Cross section through the junction of oesophagus and ventriculus, $x$ 63, Fig. 35. Cross section through ventriculus, $x$ 63, Fig. 36. Pert of cross section through the ovary, $x 160$ ch 1 - lateral chord, c exc - excretory canal, c m - muscle cells, cut - cuticle, exc - excretory gland cell, int - intestine, $n$ - nucleus of excretory gland cell, ces - esophagus, ov - ovary, ventr - ventricu- 


\section{DISCUSSION}

The adult nematodes obtained in our culture allowed the species to be identified correctly as Anisakis simplex (Rudolphi, 1809). Thus the question of the classification of the 3rd stage larvae in Baltic herring is settled.

Similarly, Pippy and Banning (1974) classified adult nematodes reared by Banning (1971) from the North Sea Anisakis larvae as Anisakis simplex. In either case the 3rd stage Anisakis larvae had long ventriculi, conical tails ended with mucrons, excretory canals opening atop the heads between the ventro-lateral lips. The larvae of this type were determined as Anisakis sp. larva (I) by Berland (1961) and as Anisakis: Type I larva by Japanese authors (Koyama et al., 1969).

All the larvae of this type occurring in many fish species of the Atlantic, Pacific and adjacent seas are very likely to belong to the same cosmopolitan species, Anisakis simplex. Earlier experimental works by Oshima (1969) and Kagei (1969) had proved that euphausid crustaceans are the first intermediate hosts for Anisakis simplex. They are the source of invasion for fish and ensure a world-wide distribution of the parasite.

\section{ACKNOWLEDGMENTS}

I owe my sincere thanks to Dr. Bolesław Uziębło, Head of the Veterinary Hygiene Department, Szczecin for supplying me with fresh cattle blood throughout the culture period. Mrs Urszula Żarska, Mr Marek Strzelichowski M.Sc. and Mrs Mirosława Żak are thanked for, respectively, preparing the microtome sections, photographing them and drawing the figures.

\section{REFERENCES}

Banning P., van, 1971: Some notes on a succesful rearing of the herring - worm, Anisakis marina L. (Nematoda: Heterocheilidae). J. Const. int. Explor. Mer, 34, 1: 84-88.

Berland B., 1961: Nematodes from some Norvegian marine fishes. Sarsia, 2: 1-50.

Chitwood B.G. and Chitwood M.B., 1950: An Introduction to Nematology. USA, Baltimore.

Chitwood M.B. and Lichtenfels J.R., 1972: Identification of Parasitic Metazoa in Tissue Sections. Exper. Parasit., 32: 407-519.

Davey J.T., 1969: The early Development of Contracaecum osculatum. J. Helminth., 43, 3/4: 293-298.

Davey J.T., 1971: A Revision of the Genus Anisakis Dujardin, 1845 (Nematoda: Ascaridata). J. Helminth 45, 1: 51-72.

Gibson D.I., 1970: Aspects of the development of "Herringworm" (Anisakis sp. Larva) in experimentally infected rats. Nytt. Mag. Zool. 18, 2: 175-187.

Grabda J., 1975: Studies on the life-history and morphogenesis of Anisakis simplex (Rudolphi, 1809) cultured in vitro. Second European Multicolloquy of Parasitology, Trogir 1-6 September 1975: $47-48$

Grainger J.N.R., 1959: The identity of the larval Nematodes found in the body muscles of the cod (Gadus callarias). Parasitology, 49: 121-131.

Kagei N., 1969: Life cycle of genus Anisakis. Saishin - Igaku, 24, 2: 389-400. 
Khalil L.F., 1969: Larval Nematodes in the herring (Clupea harengus) from British coastal waters and adjacent territories. J. mar. biol. Ass. U.K., 49: 641-659.

Koyama T., Kobayashi A., Kumada M., Komiya Y., Oshima T., Kagei N., Ishi T. and Machida M., 1969: Morphological and taxunomical studies on Anisakidae larvae found in marine fishes and squids. Jap. J. Parasit., 18, 5: 466-487.

Myers B.J., 1960: On the morphology and life history of Phocanema decipiens (Krabbe, 1878) Myers, 1959 (Nematoda: Anisakidae). Can. J. Zool., 38: 331-344.

Oshima T., 1969: A study on the first host of Anisakis. Saishin-Igaku, 24, 2: 401-404.

Oshima T., Shimazu T., Koyama H. and Akahane H., 1969: On the larvae of the genus Anisakis (Nematoda: Anisakinae) from the Euphausids. Jap. J. Parasit., 18, 3: 241-248.

Pippy J.H.C. and Banning P., van, 1974: Identification of Anisakis larva (I) as Anisakis simplex (Rud., 1809, det. Krabbe, 1878) (Nematoda: Ascaridata). Inter. Commission for the North-west Atlantic Fisheries. Serial No. 3253 (D.c. 9) ICNAF, Res. Doc. 74/47: 1-5.

Roskam R.Th., 1966: Anisakis larvae in North Sea herring. ICES CM 1966/H: 13.

Ruitenberg E.J., 1970: Anisakiasis. Pathogenesis, Serodiagnosis and Prevention. Utrecht.

Schultz H.P., 1974: Anisakis Larvae from the Herring: in vitro Development and Morphology. Third Inter. Congress of Parasitology, München 25-31 August 1974. Proc., 3: 1627.

Sommerville R.I., 1974: Physico-chemical requirements for development in vitro of Anisakis sp. larvae from fish. Third Inter. Congress of Parasitology, München 25-31 August 1974. Proc., 1: 461-462.

Thiel P.H., van. 1966: The final hosts of the herring worm Anisakis marina. Trop. geogr. Med. 18: $310-328$.

Thiel P.H., van, Kuipers F.C. and Roskam R.Th., 1960: A Nematode parasitic to herring, causing acute abdominal syndromes in man. Trop. geogr. Med., 2: 97-113.

Thiel P.H., van and Houten H., van, 1967: The localization of the herringworm Anisakis marina inand outside the human gastro-intestinal wall. Trop. geogr. Med. 19: 56-62.

Young P.C. and Lowe D., 1969: Larval nematodes from fish of the sub-family Anisakinae and gastrointestinal lesions in mammals, J. Comp. Path., 79: 301-313.

Translated: mgr Teresa Radziejewska

\section{BADANIA NAD CYKLEM ROZWOJOWYM I MORFOGENEZA \\ ANISAKIS SIMPLEX (RUDOLPHI, 1809) (NEMATODA: ANISAKIDAE) \\ W HODOWLI IN VITRO}

\section{Streszczenie}

Celem pracy było pozyskanie dorosłych nicieni z hodowli in vitro larw Anisakis III-stadium, występujących w śledziach bałtyckich i na ich podstawie oznaczenie gatunku, do jakiego te larwy należą.

Ponadto zbadano morfologię poszczególnych stadiów pozyskanych $\mathrm{z}$ hodowli i prześledzono kształtowanie się poszczególnych narządów w trakcie rozwoju pasożyta. Zwrócono przy tym uwagę na potrzebę poznania budowy wewnętrznej na przekrojach mikrotomowych, co ma duże znaczenie przy badaniu pasożytów w tkankach żywicieli.

Larwy III stadium Anisakis hodowano na pożywce z ekstraktu z wątroby wołowej z dodatkiem świeżej krwi bydlęcej w temperaturze $36-37^{\circ} \mathrm{C}$, stosując nieco zmodyfikowaną metodę Banninga (1971).

Przeprowadzono 3 serie hodowli, z których uzyskano IV-stadium larwalne, dorosłe osobniki samców i samic oraz jaja i pierwsze stadia larwalne, wylęgające się z jaj. 
Pełny okres hodowli do chwili pojawienia się jaj wynosił 23-29 dni. W tym czasie larwy dwukrotnie liniały. Pierwsza linka miała miejsce po 5-7 dniach hodowli, dając IV-stadium larwalne. Po 12-14 dniach nastąpiła druga linka, po której pojawiły się dorosłe samce i samice. Po dalszych 4-9 dniach samice zaczęły produkować jaja. Produkcja jaj trwała 14-19 dni, po czym samice ginęły.

Jaja składane są w stadium jednego blastomeru, którego bruzdkowanie następuje w wodzie i w zależności od temperatury po kilku dniach w jaju pojawia się larwa I-stadium. $\mathrm{Z}$ jaj wylęgają się larwy II-stadium otoczone pochewką kutikularną, stanowiącą wylinkę larwy I-stadium.

W oparciu o cechy taksonomiczne przyjęte przez Davey (1971) oznaczono hodowane nicienie jako Anisakis simplex (Rudolphi, 1908).

Przedstawiona wyżej hodowla larw Anisakis simplex jest drugą z kolei udaną próbą hodowli na sztucznej pożywce a pierwszą dla larw Anisakis z Bałtyku, gdzie dotychczas tego rodzaju badań nie prowadzono.

Я. Грабда

ИССЛЕДОВАНИЕ ЦИКЛА РАЗВИТИЯ И МОРФОГЕНЕЗА АNISAKIS S IМРLЕХ (RUDOIPHI, 1809) (NEMATODA: ANISAKIDAE) B KYJBTYPE IN VITRO

\section{$P$ e 3 ю 4 e}

Целью работы было получение взрослых нематод в культуре личинок Anisakis III-стадии, паразитируюших в балтийской сельди и определение на их основе вида, к которому относятся эти личинки. Кроме того, изучена морфология отдельных стадий, полученных в культуре, и прослежено формирование отдельных органов в процессе развития паразита. При этом принята во внимание необходимость изучения внутреннего строения на микротомовых разрезах, что имеет большое знячение при исследовании паразитов в тканях хозяев.

Личинки Anisakis культивировались на питательной среде из экстракта говяжьей печени с добавкой свежей коровьей крови при температуре $36^{\circ}-37^{\circ} \mathrm{C}$ по модиф̆ицированному методу Баннинга (1971).

Проведено 3 серии культивирования; в юоторых получены IV личиночная стадия, взросле особи самцов и самок, а танже яйца и первые личиночные стадии, выклёвывающися из яиц.

Полный цикл культуры с момента появления яиц составлял от 23 до 29 дней. В это время личинки дважды линяли. Первая линька наступила через 5-7 дней культивирования, дав в результате IV стадию личинки. Через 12-14 дней наступила вторая линька, после которой появились взрослые самцы и самки. Чөрез следующие 4-9 дней самки начали откладывать яйца. Этот процесс продолжался 14-19 дней, после чего самки погибали. 
Яйца откладываютя стадии одного бластомера, сегментация которого происходит в воде, и, в зависимости от температуры, через несколько дней появляется личинка I-стадии. Из яиц выклёвываются личинки II-стадии, окруғённые кутикулярным влагалищем; явяющимся шкуркой личинки I-стадии.

На основе таксономичөоких признаков, установленных Давэйем (1971), культивируемые нематоды- апределены кан Anisakis simplex (Rudolfhi, 1908).

Вышеописанная культура личинок Anlsakls simplex является второй успешной попытной юультивирования на искусственной питательной среде и первой - для личинок Anlsele1 из Балтийского моря. где такого рода исслөдования до сих пор не проводились.

Address:

Received: 12 I 1976 r.

Dr Jadwiga Grabda

Instytut Ichtiologii AR

71-550 Szczecin, ul. Kazimierza Królewicza 4

Polska - Poland 